Dept. of Animal and Clinical Nutrition,

Fac. of Vet. Med., Assiut Univ.

\title{
EFFECT OF QUANTITATIVE FEED RESTRICTION AND SUBSEQUENT REFEEDING ON PERFORMANCE AND CARCASS TRAITS OF BROILERS
}

(With 9 Tables)

By

\section{H.A. ABDEL-RAHEEM; NABILA A. GAZIA; A.M. ABD-ELLAH and GHADA Sh. ABDEL-RAHEEM (Received at 16/12/2006) \\ دراسة تأثير تقليل الغذاء مع إعادة التغذية على كفاءة الأداء وصفات الأبيحة

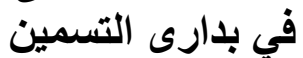

حسن عباس عبل الرحيم ، نبيله عبل الهادي جازياه ، عبل الستار عبل اللاة ، غادة عبل الرحيل

أجريت هذه الدر اسة في تجربتين لدراسة تأثير تقليل الغذاء مع اعادة التخذية الاختياريـة خـالال

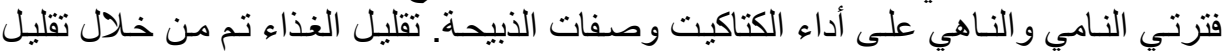

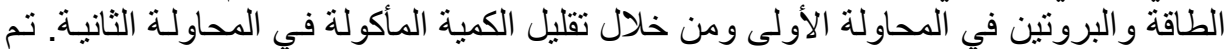

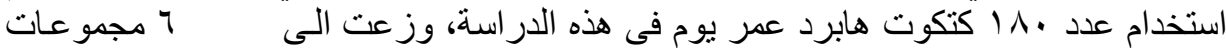

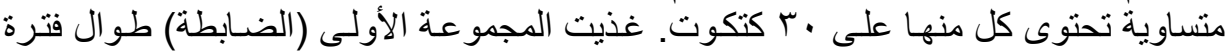

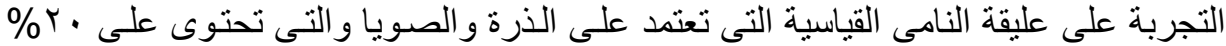

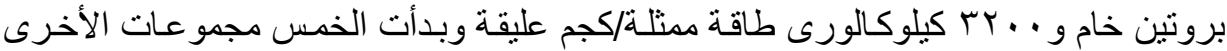

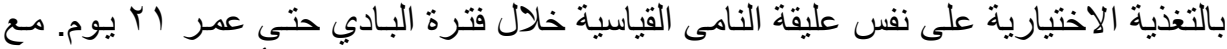

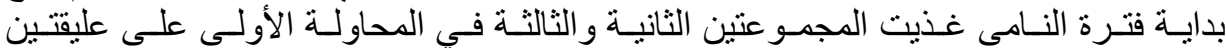

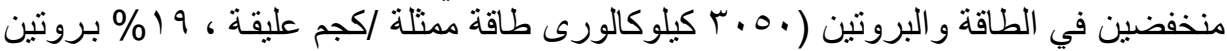

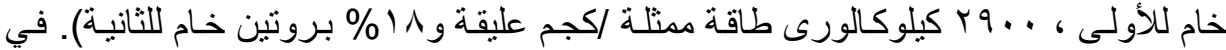

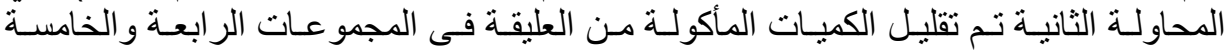

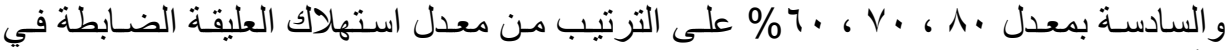

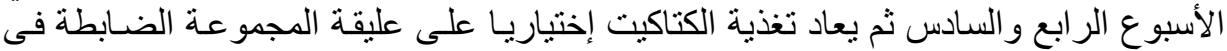

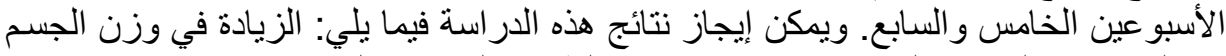

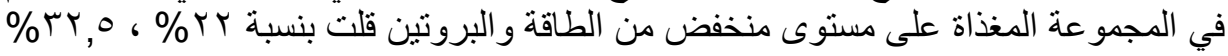

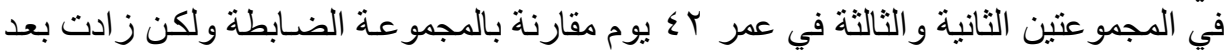

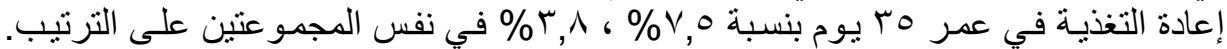

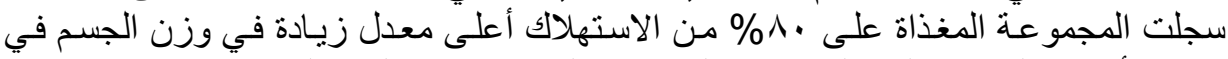

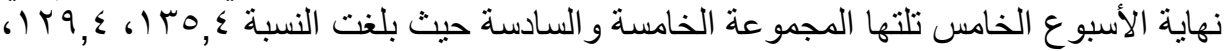




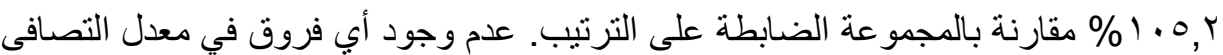

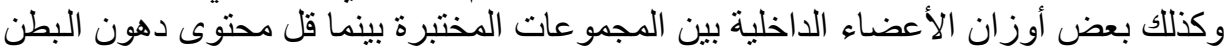

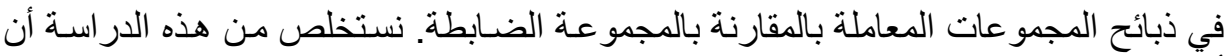

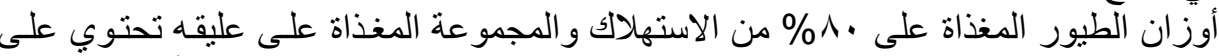

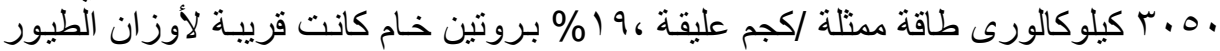
في المجموعة الضابطة.

\section{SUMMARY}

This experiment was performed to investigate the effect of different approaches of feed restriction and the implication of realimentation in alternative weeks on chick performance and carcass traits. The restriction approaches involved restriction of nutrients, protein and energy and feed intake. One hundred and eighty, day-old chicks of the Hubbard breed were weighed and allocated, at random, into six experimental groups each of 30 chicks in two trials. Birds in the first group (control) were fed ad-libitum on a broiler grower diet containing $20 \%$ crude protein $(\mathrm{CP})$ and $3200 \mathrm{kcal} \mathrm{ME} / \mathrm{kg}$. The diet was offered allover the experimental period from hatch to 7 weeks old. Chicks of the other five groups were offered the same diet in the starting stage (0-3 weeks). For the second and third groups (trial I), restriction was applied on the dietary $\mathrm{CP}$ level, keeping the $\mathrm{C} / \mathrm{P}$ ratio as that of the control. The $\mathrm{CP} \%$ was reduced by $5 \%$ for group 2 to reach 19 and $3050 \mathrm{Kcal} \mathrm{ME} / \mathrm{Kg}$ diet and by $10 \%$ for group 3 to reach $18 \%$ and $2900 \mathrm{Kcal} \mathrm{ME} / \mathrm{kg}$ diet. In the last three groups $4,5 \& 6$ (trial II), the reduction was not experimented on the nutrient density but on feed intake, restricting the intake to $80,70 \& 60 \%$ of that consumed by the control group, in a respective order. As a trial to overcome the negativity and to get advantage of the "compensatory growth" phenomenon the restriction weeks were interrupted by weeks of the ad-libitum feeding the control diet, on an alternative basis. So in the $4^{\text {th }} \& 6^{\text {th }}$ weeks was the restriction and in the $5^{\text {th }} \& 7^{\text {th }}$ was realimintation. Live weight gains of birds fed on energy-protein restricted diets were reduced by $22 \%$ in the second and $32.5 \%$ in the third group at $6^{\text {th }}$ weeks of age compared to the control one, while energy-protein realimentation at $5^{\text {th }}$ week of age resulted in an increase of weight gains by 7.3 and $3.8 \%$. The weekly body weight gain and relative growth rate of birds submitted to food restriction at $4^{\text {th }}$ and $6^{\text {th }}$ weeks of age was significantly $(\mathrm{P}<0.05)$ lower when compared to the birds fed ad-libitum. Birds were restricted to $80 \%$ had highest gains and best feed conversion ratio followed by 70 and $60 \%$ treatments, where the weight gains reached 135.4, 129.4 and $105.2 \%$ of that recorded in the 
control at $5^{\text {th }}$ week of age. No difference between treated groups and control in carcass dressing value and weights of internal organs. However the abdominal fat content was decreased in slaughtered restricted-refed birds. It could be concluded that, birds which were restricted-refed to $80 \%$ of the ad-libitum intake and those fed on $19 \% \mathrm{CP}$ \& $3050 \mathrm{kcal} \mathrm{ME} / \mathrm{kg}$ had a nearly similar final body weight to that of the control one. Incomplete body weight recovery was obtained with the other of great restrictions.

Key words: Feed restriction, broiler performance, carcass traits.

\section{INTRODUCTION}

The fundamental objective of poultry nutrition is to maximize the economic production performance of birds. Diets are formulated by least cost linear programming to provide specified levels of nutrients that are needed for optimum performance. In poultry free-choice and dry-mash feeding are both commonly applied practice. The birds have been thought to be able to regulate their intake according to their requirement and growth potential. Now food prices are so high and saving intake of food or expensive ingredient, which does not affect performance is worth to be investigated. Controlling of feed intake, diluting the nutrient density, or dispensing with an expensive distinctive ingredient, systems of restricted feeding, now command very great interest in an attempt to minimize development of excessive carcass fat or reducing the feeding cost. Early studies of food restriction resulted in better food utilization and reduced carcass fat content without reduction in final body weight (Plavnik \& Hurwitz, 1985, 1988, 1991; Jones \& Farrel, 1992 \& Santoso et al., 1995). However, others have failed to confirm this effect (Yu et al., 1990; Fontana et al., 1993; Deaton, 1995; and Zubair \& Leeson, 1996). Improvement in feed efficiency noted with the use of feed restriction programs is due to reduced overall maintenance requirements. This reduction seems to be due to a transient decrease in basal metabolic rate of feed-restricted birds (Zubair and Leeson, 1994). Lippens et al., (2000) found that, chickens subjected to an early food restriction of about $90 \%$ of the ad-libitum intake during 4 days have a comparable final body weight to that of the control group. Incomplete body weight recovery was obtained with the other more severe restrictions. Reduction in body weight gains in energy-protein restricted birds has been noted by Holsheimer \& Veerkamp (1992); Moran et al. (1992) and Bregendahl et al. (2002). An important factor influencing the variability observed in 
compensatory growth might be the condition of realimentation, greater feed intake relative to body size and nutrient requirements during the refeeding period (Zubair \& Leeson, 1996; Lippens et al., 2000 \& 2002). Adequate compensatory growth seems to be an essential condition for an improvement of the nitrogen retention of retarded birds in comparison with the ad-libitum fed birds. As the results obtained from feed restriction programs to reduce the carcass fat content in broiler chicken have been inconsistent, the present study was planned to investigate the effect of different approaches of feed restriction and the implication of realimentation in alternative weeks on chick performance and carcass traits. The restriction approaches involved restriction of nutrients, protein and energy as well as feed intake.

\section{MATERIALS and METHODS}

\section{Experimental chicks}

One hundred and eighty, day-old chicks of the Hubbard breed were weighed and allocated, at random, into six experimental groups each of 30 chicks. The chicks were floor-reared in a hygienic pen, of separate compartments which were bedded with chopped wheat straw. Fresh and clean water was constantly supplied and the diets were formulated and offered according to the designed feeding system in each trial. All birds were kept under hygienic conditions and were subjected to a prophylactic vaccination and pharmacological program against viral and bacterial diseases.

\section{Experimental design:}

To investigate how to reduce the feeding cost and to minimize the development of excessive carcass fat, quantitative feed restriction and realimentation was tried in this experiment which was conducted in two feeding trials. In the first trial, the crude protein (CP) and energy density of the control diet were adjusted at two levels, while the feed intake was restricted at three levels, as percentages of that consumed by the control group, in the second trial.

\section{Diets and feeding:}

Birds in the first group which were considered as control were fed ad-libitum on a broiler grower diet (one diet-system) containing 20\% $\mathrm{CP}$ and $3200 \mathrm{kcal} \mathrm{ME} / \mathrm{kg}$. The diet was offered allover the experimental period from one-day to 7 weeks old. Chicks of the other five groups were offered the same diet in the starting stage (0-3 weeks), then each of them was treated according to the suggested design going to be tested. In groups 2 and 3, restriction was tried on the dietary CP level, keeping the 
calorie/protein ratio as that of the control. The CP\% was reduced by $5 \%$ for group 2 to reach 19 (and $3050 \mathrm{Kcal} \mathrm{ME} / \mathrm{Kg}$ diet) and by $10 \%$ for group 3 to reach $18 \%$ (and $2900 \mathrm{Kcal} \mathrm{ME} / \mathrm{kg}$ diet). In the last three groups $4,5 \& 6$, the reduction was not tried on the nutrient density but on feed intake, by restricting the intake to $80,70 \& 60 \%$ of that consumed by the control group, in a respective order. For the amount of food, specified for each group to be known, feeding of the control group started a week earlier than the restricted intake-ones. The restriction approaches, either in nutrient densities or feed intake, were executed after 3 weeks of age. The most rapid rate, is curtailed. Also, the restriction in a week was alternatively followed by another week of realimentation in order to get use of the "compensatory growth" phenomenon as animals have the tendency to "store" their growth potential and regain what is lost in their growth curves. So restrictions were followed on the $4^{\text {th }}$ and $6^{\text {th }}$ weeks, and realimentations on the $5^{\text {th }}$ and $7^{\text {th }}$ weeks of age. The following table summarizes the applied experimental design.

\begin{tabular}{|c|c|c|c|c|c|c|}
\hline \multirow{2}{*}{ Weeks } & \multirow{2}{*}{$\begin{array}{l}\text { Control } \\
\text { group } \\
1\end{array}$} & \multicolumn{2}{|c|}{$\begin{array}{l}\text { Trial I } \\
\text { groups }\end{array}$} & \multicolumn{3}{|c|}{$\begin{array}{l}\text { Trial II } \\
\text { Groups }\end{array}$} \\
\hline & & 2 & 3 & 4 & 5 & 6 \\
\hline \multicolumn{7}{|c|}{ Starting phase $(0-3$ weeks $)$} \\
\hline \multirow{2}{*}{\multicolumn{4}{|c|}{$\begin{array}{l}\text { Feed intake } \\
\text { C P \% }\end{array}$}} & \multirow{2}{*}{\multicolumn{3}{|c|}{ d-libitum }} \\
\hline & & & & & & \\
\hline \multicolumn{4}{|l|}{$\mathrm{ME}(\mathrm{Kcal} / \mathrm{kg})$} & \multicolumn{3}{|c|}{200} \\
\hline \multicolumn{4}{|c|}{ Growing-finishing phase ( $4-7$ weeks) } & \multirow{5}{*}{$80 \%$} & \multirow{5}{*}{$\begin{array}{l}70 \% \\
20 \% \\
3200\end{array}$} & \multirow{5}{*}{$60 \%$} \\
\hline \multicolumn{4}{|c|}{ Weeks 4 \& 6 (restriction) } & & & \\
\hline Feed intake & & -libitu & & & & \\
\hline С P \% & 20 & 19 & 18 & & & \\
\hline $\mathrm{ME}(\mathrm{Kcal} / \mathrm{kg})$ & 3200 & 3050 & 2900 & & & \\
\hline \multicolumn{7}{|c|}{$\begin{array}{l}\text { Weeks } 5 \text { \& } 7 \text { (realimentation) } \\
\text { Ad-libitum refeeeding of the control diet which contained } 20 \% \mathrm{CP} \& 3200 \\
\qquad \mathrm{Kcal} \mathrm{ME} / \mathrm{kg} \text { diet }\end{array}$} \\
\hline
\end{tabular}

The tested diets were formulated from the commonly used ingredients which were chemically analyzed for their nutrient composition following AOAC procedures (1984), while their ME value, calcium, phosphorous, methionine, lysine and cystine contents were derived from the feed composition tables given in the NRC publication (1994).

Table 1: Chemical composition (\%) and metabolizable energy value of the used diet ingredients 
Assiut Vet. Med. J. Vol. 53 No. 112 January 2007

\begin{tabular}{|c|c|c|c|c|c|}
\hline Feedstuff & $\begin{array}{c}\text { Yellow } \\
\text { corn }\end{array}$ & $\begin{array}{c}\text { Fish meal } \\
\text { (herring) }\end{array}$ & $\begin{array}{c}\text { Soybean } \\
\text { oil meal }\end{array}$ & $\begin{array}{c}\text { Wheat } \\
\text { bran }\end{array}$ & $\begin{array}{c}\text { Dried fat } \\
* *\end{array}$ \\
\cline { 1 - 4 } Drtrient composition & 89.40 & 92.60 & 89.50 & 88.80 & 99.00 \\
Crude protein & 8.30 & 71.20 & 45.00 & 15.90 & - \\
Ether extract & 4.00 & 9.60 & 0.90 & 3.30 & 99.00 \\
Crude fibre & 2.40 & 0.77 & 7.90 & 5.20 & - \\
Ash & 5.00 & 9.10 & 6.30 & 10.50 & - \\
Nitrogen free-extract & 69.70 & 1.93 & 29.40 & 53.90 & - \\
ME Kcal/Kg* & 3350.0 & 3190.0 & 2230.0 & 1300.0 & 7500.0 \\
Ca \% $*$ & 0.02 & 2.29 & 0.29 & 0.14 & - \\
Available P \%* & 0.08 & 1.7 & 0.27 & 0.20 & - \\
Lysine \%* & 0.26 & 5.47 & 2.69 & 0.61 & - \\
Methionine \%* & 0.18 & 2.16 & 0.62 & 0.23 & - \\
Cystine \%* & 0.18 & 0.72 & 0.66 & 0.32 & - \\
\hline
\end{tabular}

* Derived from NRC publication (1994) * * Ultracal dried fat (EGAVET)

Table 2: The ingredient and chemical composition (\% or $\mathrm{Kcal} / \mathrm{Kg}$ ) of the diets fed for the different experimental groups

\begin{tabular}{|c|c|c|c|}
\hline \multirow{2}{*}{ Item } & \multirow{2}{*}{ Control diet } & \multicolumn{2}{|c|}{$\mathrm{C} / \mathrm{P}$ restricted diets } \\
\hline & & $19 \% \mathrm{CP}$ & $18 \% \mathrm{CP}$ \\
\hline \multicolumn{4}{|l|}{ Ingredient composition } \\
\hline Corn (yellow) & 59.48 & 63.05 & 64.30 \\
\hline Soybean oil meal & 27.15 & 22.82 & 18.66 \\
\hline Fish meal & 4.00 & 4.00 & 4.00 \\
\hline Dried Fat & 6.32 & 3.31 & 1.15 \\
\hline Wheat bran, fine & - & 4.00 & 9.00 \\
\hline Dicalcium phosphate & 1.23 & 0.97 & 0.95 \\
\hline Limestone (ground) & 1.18 & 1.24 & 1.34 \\
\hline Common salt & 0.32 & 0.31 & 0.30 \\
\hline D-Methionine & 0.02 & - & - \\
\hline Premix* & 0.30 & 0.30 & 0.30 \\
\hline \multicolumn{4}{|c|}{ Chemical composition and energy value } \\
\hline Metabolizable energy, Kcal $/ \mathrm{kg}$ & 3200 & 3050 & 2900 \\
\hline Crude Protein $(\%)$ & 20.01 & 19.00 & 18.00 \\
\hline Calorie/protein ratio & 159.9 & 160.5 & 161.1 \\
\hline $\mathrm{Ca} \%$ & 0.90 & 0.90 & 0.90 \\
\hline Available P \% & 0.35 & 0.30 & 0.30 \\
\hline Lysine \% & 1.10 & 1.02 & 1.01 \\
\hline Methionine \% & 0.22 & 0.35 & 0.35 \\
\hline
\end{tabular}

* Vigora premix (vitamins and Minerals)

The studied measurements:

Growth performance and feed conversion: 
The amount of feed consumed was weekly recorded for the different groups. The average amount consumed by each bird was calculated by dividing the weekly consumed food by its respective number of birds in each group at this week. Regarding the development of the body weight and weight gain, the birds were individually weighed every week and the live weight changes were taken as the criteria of the effect of the different treatments, and as a measure for growth. The standard deviations and errors were calculated. The measured growth was expressed in percentage relative to the body weight in order to compare the different groups in relation to their relative rate of growth.

The amount of feed consumed was divided by the body weight gain of the bird in order to calculate the feed conversion ratio. Experimental crude data were subjected to several statistical analysis, from which the means, standard errors were calculated and differences were tested for significancy using $(t)$ test (SAS, 1990).

\section{Carcass traits, and chemical composition:}

Five randomly selected birds from each group were slaughtered at the end of the experiment for evaluating carcass traits and meat chemical composition. Feed but not water was unavailable for birds 12 hours prior to slaughtering. Dressed carcass weight as the weight of the slaughtered birds after removal of feathers, head and feet but including all the offal's, (edible or not) was recorded. The weights of some internal organs of birds including gizzard, proventriculus, liver, spleen and heart as well as visible abdominal fat were recorded as an absolute weight or relative to the weight of the dressed carcass.

\section{Monetary value:}

Total production cost was calculated including prices of one day old chicks, feeds, heating, veterinary care, management and housing. Selling price was calculated by multiplying total live body weight of the birds produced by the price per unit weight commonly offered in the market.

Net revenue $=$ Selling price - Total production costs

Economic feed efficiency $(\mathrm{EFE})=\frac{\text { Net revenue }}{\text { Total production } \cos t s}$

Relative economic feed efficiency (REFE) $=\frac{\text { EFE of group }}{\text { EFE of control }} \times 100$

\section{RESULTS}


The results obtained for chick performance in terms of body weight development, relative growth rate, feed intake and feed conversion are presented in Tables 3, 4, 5 and 6. Chemical composition of broiler meat and carcass traits are given in Tables $7 \& 8$. The economical evaluation of broiler performance in different experimental groups in the two trials is shown in Table 9.

Table 3: Body weight development of broiler chicks in trials I and II compared with the control

\begin{tabular}{|c|c|c|c|c|c|c|}
\hline AGE & Control & \multicolumn{2}{|c|}{ Trial I Groups } & \multicolumn{3}{|c|}{ Trial II Groups } \\
\cline { 2 - 7 }$($ Weeks $)$ & 1 & 2 & 3 & 4 & 5 & 5 \\
\hline 0 & 45.4 & 46.3 & 46.4 & 46.4 & 46.8 & 45.6 \\
& $\pm 1.36^{\mathrm{a}}$ & $\pm 1.35^{\mathrm{a}}$ & $\pm 1.08^{\mathrm{a}}$ & $\pm 1.08^{\mathrm{a}}$ & $\pm 1.46^{\mathrm{a}}$ & $\pm 1.69^{\mathrm{a}}$ \\
1 & 166.2 & 164.2 & 164.5 & 161.0 & 165.8 & 156.8 \\
& $\pm 2.59^{\mathrm{a}}$ & $\pm 3.62^{\mathrm{a}}$ & $\pm 4.54^{\mathrm{a}}$ & $\pm 4.09^{\mathrm{a}}$ & $\pm 4.58^{\mathrm{a}}$ & $\pm 5.55^{\mathrm{ab}}$ \\
2 & 329.0 & 327.5 & 321.0 & 323.0 & 321.7 & 334.0 \\
& $\pm 9.27^{\mathrm{a}}$ & $\pm 7.39^{\mathrm{a}}$ & $\pm 9.51^{\mathrm{a}}$ & $\pm 8.80^{\mathrm{a}}$ & $\pm 7.74^{\mathrm{a}}$ & $\pm 7.97^{\mathrm{a}}$ \\
3 & 698.0 & 684.0 & 669.0 & 685.0 & 657.0 & 675.0 \\
& $\pm 9.69^{\mathrm{a}}$ & $\pm 8.48^{\mathrm{ab}}$ & $\pm 12.08^{\mathrm{b}}$ & $\pm 13.29^{\mathrm{ab}}$ & $\pm 8.00^{\mathrm{b}}$ & $\pm 9.75^{\mathrm{ab}}$ \\
4 & 1056.0 & 1038.0 & 992.5 & 920.0 & 839.0 & 813.0 \\
& $\pm 12.99^{\mathrm{a}}$ & $\pm 18.55^{\mathrm{a}}$ & $\pm 11.99^{\mathrm{b}}$ & $\pm 19.49^{\mathrm{c}}$ & $\pm 10.88^{\mathrm{d}}$ & $\pm 10.91^{\mathrm{e}}$ \\
5 & 1440.0 & 1452.0 & 1392.0 & 1440.0 & 1336.0 & 1217.0 \\
& $\pm 11.83^{\mathrm{a}}$ & $\pm 16.44^{\mathrm{a}}$ & $\pm 10.68^{\mathrm{b}}$ & $\pm 16.43^{\mathrm{a}}$ & $\pm 15.03^{\mathrm{c}}$ & $\pm 11.19^{\mathrm{d}}$ \\
& 1686.0 & 1644.0 & 1558.0 & 1608.0 & 1468.0 & 1359.0 \\
& $\pm 15.47^{\mathrm{a}}$ & $\pm 14.27^{\mathrm{ab}}$ & $\pm 10.19^{\mathrm{c}}$ & $\pm 10.19^{\mathrm{b}}$ & $\pm 8.60^{\mathrm{d}}$ & $\pm 14.18^{\mathrm{e}}$ \\
7 & 1965.0 & 1875.0 & 1816.0 & 1896.0 & 1773.0 & 1626.0 \\
& $\pm 27.94^{\mathrm{a}}$ & $\pm 21.46^{\mathrm{a}}$ & $\pm 22.27^{\mathrm{b}}$ & $\pm 19.8^{\mathrm{b}}$ & $\pm 21.6^{\mathrm{c}}$ & $\pm 20.66^{\mathrm{d}}$ \\
\hline Times of & 43.28 & 40.41 & 39.14 & 40.68 & 37.88 & 35.66 \\
initial & & & & & & \\
\hline Mortality & 3 & 2 & 2 & 3 & 2 & 2 \\
\hline
\end{tabular}

Figures in the same row having the same superscripts are not significantly different $(\mathrm{P}<0.05)$

Table 4: Relative growth rate of the different experimental groups

\begin{tabular}{|c|c|c|c|c|c|c|}
\hline \multirow{2}{*}{$\begin{array}{l}\text { Experimental } \\
\text { period (weeks) }\end{array}$} & $\begin{array}{c}\text { Control } \\
\text { group }\end{array}$ & \multicolumn{2}{|c|}{$\begin{array}{c}\text { Trial I } \\
\text { groups }\end{array}$} & \multicolumn{3}{c|}{$\begin{array}{c}\text { Trial II } \\
\text { Groups }\end{array}$} \\
\cline { 2 - 7 } & 1 & 2 & 3 & 4 & 5 & 6 \\
\hline $0-1$ & 114.18 & 111.87 & 111.99 & 110.51 & 111.95 & 109.88 \\
$1-2$ & 65.75 & 66.42 & 64.47 & 66.94 & 63.96 & 72.21 \\
$2-3$ & 71.86 & 70.49 & 70.30 & 71.83 & 68.52 & 67.59 \\
$3-4$ & 40.82 & 41.11 & 38.94 & 29.28 & 24.33 & 18.55 \\
$4-5$ & 30.77 & 30.54 & 33.51 & 44.07 & 45.70 & 39.80 \\
$5-6$ & 14.55 & 12.02 & 11.25 & 11.72 & 9.42 & 11.02 \\
$6-7$ & 8.23 & 13.13 & 15.84 & 13.78 & 18.82 & 17.89 \\
\hline
\end{tabular}

Table 5: The weekly feed consumption (g/chick) of the different treated groups 
Assiut Vet. Med. J. Vol. 53 No. 112 January 2007

\begin{tabular}{|c|c|c|c|c|c|c|}
\hline \multirow{2}{*}{$\begin{array}{c}\text { Experimental } \\
\text { period (weeks) }\end{array}$} & $\begin{array}{c}\text { Control } \\
\text { group }\end{array}$ & \multicolumn{2}{|c|}{$\begin{array}{c}\text { Trial I } \\
\text { groups }\end{array}$} & \multicolumn{3}{c|}{$\begin{array}{c}\text { Trial II } \\
\text { Groups }\end{array}$} \\
\cline { 2 - 7 } & 1 & 2 & 3 & 4 & 5 & 6 \\
\hline $0-1$ & 131.3 & 125.3 & 127 & 128.3 & 135.9 & 120 \\
$1-2$ & 341.5 & 319.6 & 306.3 & 337.5 & 341.4 & 339.1 \\
$2-3$ & 512.7 & 581.8 & 551.7 & 565.4 & 553.6 & 585.2 \\
$3-4$ & 607 & 722.14 & 690.3 & 487.9 & 412.5 & 352.9 \\
$4-5$ & 880.3 & 946.8 & 925.5 & 928.3 & 997.3 & 958 \\
$5-6$ & 917.9 & 984.6 & 972.9 & 735 & 647.1 & 550.6 \\
$6-7$ & 1000 & 1004.3 & 1033.3 & 976.9 & 996.4 & 1014.4 \\
\hline $0-7$ & 4390.7 & 4684.5 & 4607.0 & 4159.3 & 3984.2 & 3899.8 \\
\hline
\end{tabular}

Table 6: Chick performance of the experimental groups in trials I and II compared with the control

\begin{tabular}{|c|c|c|c|c|c|c|}
\hline \multirow[t]{2}{*}{$\begin{array}{r}\text { Experimental } \\
\text { period (weeks) }\end{array}$} & \multirow{2}{*}{$\begin{array}{l}\text { Control } \\
\text { group }\end{array}$} & \multicolumn{2}{|c|}{$\begin{array}{c}\text { Trial I } \\
\text { Groups }\end{array}$} & \multicolumn{3}{|c|}{$\begin{array}{l}\text { Trial II } \\
\text { Groups }\end{array}$} \\
\hline & & 2 & 3 & 4 & 5 & 6 \\
\hline \multicolumn{7}{|l|}{ Feed intake } \\
\hline $4^{\text {th }}$ weeks & 607.0 & 722.1 & 690.3 & 487.9 & 412.5 & 352.9 \\
\hline $5^{\text {th }}$ weeks & 880.3 & 946.6 & 925.5 & 926.3 & 997.3 & 958.0 \\
\hline $6^{\text {th }}$ weeks & 917.9 & 984.6 & 972.3 & 735.0 & 647.1 & 550.6 \\
\hline $7^{\text {th }}$ weeks & 1000.0 & 1004.3 & 1033.3 & 976.9 & 996.4 & 1014.4 \\
\hline $0-7$ & 4390.7 & 4684.5 & 4607.0 & 4159.3 & 3984.2 & 3899.8 \\
\hline \multicolumn{7}{|c|}{ Body weight gain } \\
\hline $4^{\text {th }}$ weeks & $358 \pm 15.9$ & $354 \pm 7.9$ & $323.5 \pm 12.2$ & $235 \pm 8.4$ & $182 \pm 13.7$ & $138 \pm 3.6$ \\
\hline $5^{\text {th }}$ weeks & $384 \pm 16.7$ & $414 \pm 15.6$ & $399.5 \pm 9.9$ & $520 \pm 5.5$ & $497 \pm 7.4$ & $404 \pm 12.2$ \\
\hline $6^{\text {th }}$ weeks & $246 \pm 14.0$ & $192 \pm 10.6$ & $166 \pm 7.45$ & $168 \pm 7.4$ & $132 \pm 8.0$ & $142 \pm 8.6$ \\
\hline $7^{\text {th }}$ weeks & $279 \pm 19.8$ & $231 \pm 18.7$ & $258 \pm 12.8$ & $288 \pm 17.3$ & $305 \pm 11.9$ & $267 \pm 17.1$ \\
\hline $0-7$ & $\begin{array}{c}1919.6 \\
\pm 56.59^{\mathrm{a}}\end{array}$ & $\begin{array}{c}1828.6 \\
\pm 41.23^{\mathrm{b}}\end{array}$ & $\begin{array}{c}1769.6 \\
\pm 21.71^{\mathrm{b}}\end{array}$ & $\begin{array}{c}1849.6 \\
\pm 46.15^{\mathrm{a}}\end{array}$ & $\begin{array}{c}1726.2 \\
\pm 47.89^{\mathrm{e}}\end{array}$ & $\begin{array}{c}1580.4 \\
\pm 49.15^{\mathrm{d}}\end{array}$ \\
\hline \multicolumn{7}{|c|}{ Feed conversion ratio } \\
\hline $4^{\text {th }}$ weeks & 1.69 & 2.04 & 2.13 & 2.08 & 2.27 & 2.56 \\
\hline $5^{\text {th }}$ weeks & 2.29 & 2.29 & 2.31 & 1.79 & 2.01 & 2.37 \\
\hline $6^{\text {th }}$ weeks & 3.73 & 5.13 & 5.86 & 4.38 & 4.90 & 3.88 \\
\hline $7^{\text {th }}$ weeks & 3.58 & 4.35 & 4.01 & 3.39 & 3.27 & 3.79 \\
\hline $0-7$ & 2.29 & 2.53 & 2.60 & 2.25 & 2.31 & 2.47 \\
\hline
\end{tabular}

Figures in the same row having the same superscripts are not significantly different $(\mathrm{P}<0.05)$

Table 7: Dressed carcass and some internal organs as a percentage of live body weight of the chicks in different experimental groups

\begin{tabular}{|c|c|c|c|}
\hline Item (\%) & $\begin{array}{c}\text { Control } \\
\text { group }\end{array}$ & $\begin{array}{c}\text { Trial I } \\
\text { Groups }\end{array}$ & $\begin{array}{c}\text { Trial II } \\
\text { Groups }\end{array}$ \\
\hline
\end{tabular}


Assiut Vet. Med. J. Vol. 53 No. 112 January 2007

\begin{tabular}{|c|c|c|c|c|c|c|}
\hline & 1 & 2 & 3 & 4 & 5 & 6 \\
\hline Dressed carcass & 82.90 & 78.93 & 76.65 & 79.69 & 83.42 & 84.69 \\
Gizzard & 2.65 & 2.27 & 2.37 & 2.28 & 2.62 & 2.39 \\
Proventriculus & 0.72 & 0.66 & 0.75 & 0.62 & 0.67 & 0.65 \\
Liver & 3.24 & 2.28 & 2.19 & 2.21 & 2.87 & 2.55 \\
Spleen & 0.19 & 0.16 & 0.16 & 0.17 & 0.17 & 0.15 \\
Heart & 0.59 & 0.59 & 0.73 & 0.57 & 0.75 & 0.76 \\
\hline Abdominal fat & 1.38 & 1.18 & 1.10 & 1.07 & 1.11 & 1.09 \\
\hline
\end{tabular}

Table 8: Chemical composition (\%) of broiler's meat in different

\begin{tabular}{|c|c|c|c|c|}
\hline \multirow{2}{*}{ ITEM } & \multirow{2}{*}{ DM } & \multicolumn{3}{|c|}{ ON DM BASIS } \\
\cline { 3 - 5 } GROUPS & & CP & EE & Ash \\
\hline Control & & & & \\
1 & 24.46 & 82.60 & 130.0 & 3.66 \\
\hline Trial I & & & & \\
2 & 28.30 & 81.88 & 12.85 & 3.95 \\
3 & 27.20 & 80.83 & 12.96 & 4.00 \\
\hline Trial II & & & & \\
4 & 26.84 & 83.25 & 13.02 & 3.61 \\
5 & 26.76 & 81.63 & 12.50 & 3.92 \\
6 & 25.90 & 80.25 & 12.46 & 3.21 \\
\hline
\end{tabular}

Table 9: Economical evaluation of broiler performance in different experimental groups compared with the control.

\begin{tabular}{|c|c|c|c|c|c|c|}
\hline \multirow{2}{*}{ Parameters } & Control & \multicolumn{2}{|c|}{ Trial I Groups } & \multicolumn{3}{|c|}{ Trial II Groups } \\
\cline { 2 - 7 } & 1 & 2 & 3 & 4 & 5 & 6 \\
\hline $\begin{array}{c}\text { Total feed cost (L.E) } \\
\text { Total production cost } \\
\text { (L.E) }\end{array}$ & 9.98 & 7.18 & 7.08 & 6.57 & 6.454 & 6.19 \\
$\begin{array}{c}\text { Body weight } \\
\text { (g/chick) }\end{array}$ & 1965 & 1875 & 1816 & 1896 & 1773 & 1626 \\
$\begin{array}{c}\text { Price of body weight } \\
\text { (L.E) }\end{array}$ & 11.79 & 11.25 & 10.89 & 11.38 & 10.64 & 9.76 \\
$\begin{array}{c}\text { Net revenue (L.E) } \\
\text { Economic feed } \\
\text { efficiency (\%) }\end{array}$ & 2.31 & 1.57 & 1.31 & 2.31 & 1.69 & 1.07 \\
\hline $\begin{array}{c}\text { Relative economic } \\
\text { feed efficiency \% }\end{array}$ & 100 & 66.2 & 55.9 & 106.3 & 79.2 & 52.3 \\
\hline
\end{tabular}

\section{DISCUSSION}

Broilers are fed multiple-stage diets, meaning that the composition is changed with advancing age. Alternatively, a two-stage 
system with a starter and finisher diet may be used. A third conventionally known system is the feeding of one diet containing from 20-22\% CP allover the feeding period from hatch to marketing at 7 or 8 weeks (Allam, 1986). In this experiment the one-diet system was followed using the $20 \%$ level for CP and $3200 \mathrm{kcal} / \mathrm{kg}$ diet for ME, the nutrient densities of the grower diet.

\section{Chick performance:}

In the starting phase (0-3 weeks), there were no significant difference in the live body weight between all treated groups in trial I \& II and control where chicks consumed the same diet containing $20 \% \mathrm{CP}$ and $3200 \mathrm{kcal} / \mathrm{kg} \mathrm{ME}$. The average body weight in all groups ranged from 657 to $698 \mathrm{gm}$.

\section{A- Energy- protein restriction (nutrient density dilution, trial I):}

In this trial, protein as the most expensive nutrient besides, energy and their content was reduced in growing and finishing diets, taking advantage of growth storage potential and compensatory growth as a biological phenomenon (Doyle \& lesson, 1996 and Lawrence \& Fowler, 1997).

Live body weight of broiler chicks at four week of age fed energy-protein restricted diet $(2900 \mathrm{Kcal} / \mathrm{kg} \mathrm{ME} \& 18 \% \mathrm{CP})$ was decreased compared to those fed control deit. On the other hand, chicks in the second group fed on diet containing $3050 \mathrm{Kcal} / \mathrm{kg} \mathrm{ME} \mathrm{\&} \mathrm{19 \% CP}$ had no significant effect $(\mathrm{P}<0.05)$ on mean body weight at the same previous age. Live weight gains of birds fed on energy-protein restricted diets were reduced by $22 \%$ in the second and $32.5 \%$ in the third group at $6^{\text {th }}$ weeks of age compared to control one. Reduction in body weight gains in dietary energy-protein restricted birds is in agreement with observations of Holsheimer \& Veerkamp (1992); Moran et al. (1992) and Bregendahl et al. (2002). Energy and protein realimentation at $5^{\text {th }}$ weeks of age resulted in an increase of weight gain by 7.3 and $3.8 \%$ in the second and third groups, respectively. These results indicated that protein restriction increases the ability of the chicken to absorb some amino acids (Gous, 1977) when the limiting nutrient is supplied in the recovery period, and it is not a matter of growth compensation but a matter of potential increasing. Similar results have been reported by Abdel-Hafeez et al. (2001).

Birds in the second and third groups recorded high feed consumption when compared with control at restricted and realimentation periods. In the whole experimental period, broilers consumed an average of 89.6, 95.6 and $94.0 \mathrm{~g} / \mathrm{bird}$ daily for control and 
two restricted groups respectively. Zubair \& Leeson $(1994,1996)$ stated that enhancement of feed intake in restricted-refed broilers might be attributed to the relative enlargement of digestive organs, especially crop, pancreas and liver and this help to support compensatory growth. Fisher (1984) stated that broilers tend to increase their feed intake to make up for deficiencies when fed diets that are marginally deficient in crude protein. In contrary Plavnik \& Hurwitz (1990) found that feed intake is depressed by feeding diets that are severely deficient in crude protein. The feed efficiency reduced and feed conversion indices increased during restriction periods ( $4^{\text {th }}$ and $6^{\text {th }}$ weeks), while feed conversion was nearly similar after energy and protein realimentation at $5^{\text {th }}$ weeks of age.

\section{B- Feed intake- restriction (trial II):}

The weekly body weight gain and relative growth rate of birds submitted to food restriction at $4^{\text {th }}$ and $6^{\text {th }}$ weeks of age was significantly $(\mathrm{P}<0.05)$ lower when compared to the birds fed ad-libitum. The retardation of growth was more pronounced for the $70 \& 60 \%$-restricted birds (182 and 138g Vs $358 \mathrm{~g}$ for control) in the first stage and (132 $\& 142 \mathrm{~g}$ vs $246 \mathrm{~g}$ for control) in the second stage of restriction. Concerning the weight gain, relative growth rate and feed conversion index during the first realimentation period ( $5^{\text {th }}$ weeks), there were significant $(\mathrm{P}<0.05)$ differences between the different experimental groups and control. Birds of the $80 \%$ restricted group had highest gains and lowest feed conversion index followed by 70 and $60 \%$ treatments, where the weight gains reached 135.4, 129.4 and $105.2 \%$ of that recorded in the control. In the second realimentation period ( $7^{\text {th }}$ weeks), the weight gain and feed conversion index was nearly similar between different experimental groups and control. An important factor influencing the variability observed in compensatory growth might be the condition of realimentation and nutrient requirements during the refeeding period (Lippens et al., 2000 \& 2002). Adequate compensatory growth seems to be an essential condition for an improvement of the nitrogen retention of retarded birds in comparison with the ad-libitum fed birds. According to Buyse et al. (1996) and Kuehn et al. (1996), the enhanced nitrogen efficiency can be attributed to higher concentrations of circulating growth hormone $(\mathrm{GH})$ and insulin-like growth factor-1 during compensatory growth. Ad-libitum feeding increased feed intake in the different experimental groups (80, 70 and 60\%) by 16.8, 13.2 and $8.8 \%$ respectively when compared with control at the end of first realimentation period while, feed consumption was nearly similar at $7^{\text {th }}$ 
weeks of age. A full compensation for the weight retardation during restriction periods was not obtained within a growth period of 5 and 7 weeks with the highest restriction levels (60 and 70\%). However, final body weight of $80 \%$ restricted birds did not differ significantly from those of the ad-libitum-fed control. This may be due to restricted birds converted their food more efficiently in comparison with the control. Besides, greater efficiency, there was a positive effect of food restrictions on mortality. These results agree with those reported by Leeson \& Zubair (1997), Lippens et al. (2000, 2002) who found that $80 \%$ food restriction gave complete recovery of the body weight at the age of 42 day.

\section{Carcass traits:}

Slaughter studies revealed no significant difference $(\mathrm{P}<0.05)$ among energy-protein and feed intake-restricted groups in carcass dressing value and weights of internal organs (Table 7) except restriction feed intake to $60 \%$ of ad-libitum caused a slightly improvement in dressing carcass values. These coincide with the findings of Palo et al. (1995); Walaa Abdel-Razik (1995); Leeson \& Zubair (1997) and AbdelHafeez et al. (2001). Also Leeson et al. (1991), Zubair \& Leeson (1994) and Palo et al. (1995) could not demonstrate any effect of food restriction on dressing percentage. On the other hand, Saleh et al. (1996) showed a trend of increasing dressing percentage for restricted birds as well as an improvement in breast meat yield.

At the age of 49-day, the visible abdominal fat as a pecentage of live body weight was decreased in slaughtered restricted-refed birds. Such a reduction in abdominal fat is in accord with results from Jones \& Wiseman (1985), Plavnik \& Hurwitz (1985), and Urdaneta-Rincon \& Leeson (2002). In contrast to the result obtained in current experiment, Walaa Abdel-Razik (1995) and Alleman et al. (2000) found that abdominal fat weight increased with reducing crude protein levels in the diets of broilers. Reduction in the abdominal fat deposition in feed restricted birds may be attributed to differential effect of fat depots by the altered growth trajectory induced by temporary growth retardation. Also the effect of food restriction on total fat content remains unclear. Differences in type of broiler, environmental circumstances or perhaps the rate of compensatory growth might be some of the other reasons for variable results (Lippens et al., 2002).

\section{Chemical composition of the meat:}

Dry matter, crude protein, fat and ash content (Table 8) were not altered by energy-protein or feed intake restriction, indeed, restricting 
chickens to $80 \%$ of ad-libitum intake slightly increased the protein content. These results are in agreement with Palo et al. (1995) who reported that percentages of carcass fat, crude protein, ash and dry matter were not affected by feed restriction.

\section{Economical evaluation (Monetary value):}

Economical feed efficiency of 70\%-restricted group (fifth group) was reduced by about $26.2 \%$ when compared with control. The reducing effect became more clear in the chicks fed on energy and protein restricted diets (second and third groups) and also in the 60\% restricted group during the whole experimental period (66.2, 55.9 and $52.3 \%)$. On the contrary, the third group fed on $80 \%$ restricted diet had an increasing economical feed efficiency by about $6 \%$ when compared with control (Table 9). The present experiment concluded that, birds which were restricted-refed to $80 \%$ of the ad-libitum intake and others fed on $19 \%$ $\mathrm{CP} \& 3050 \mathrm{kcal} / \mathrm{kg}$ ME containing diet had a near final body weight to that of the control one. Incomplete body weight recovery was obtained for the others of great restricted groups.

\section{REFERENCES}

Abdel-Hafeez, H.M.; Hegazi, S.M.; Saleh, S.E. and Tawfik, S.S. (2001): Effect of restricted protein nutrition and realimentation on broiler performance. Assiut Vet. Med. J., 45 (90): 24-42.

Allam, S. (1986): Poultry breeding \& management. $7^{\text {th }}$ ed. Egypt Anglo Press, pp. 205.

Alleman, F.; Michel, J.; Chagneau, A.M. and Leclerq, B. (2000): The effects of dietary protein independent of essential amino acids on growth and body compostion in genetically lean and fat chickens. Br. Poult. Sci., 41: 214-218.

AOAC (Association of Official Analytical Chemists) (1984): Official Methods of analysis ( $14^{\text {th }}$ Ed.) AOAC, Washington, DC.

Bregendahl, K.; Sell, J.L. and Zimmerman, D.R. (2002): Effect of low protein diets on growth performance and body composition of broiler chicks. Poult. Sci., Aug; 81(8): 1156-1167.

Buyse, J.; Kuhn, E.R. and Decuypere, E. (1996): The use of intermittent lighting in broiler raising 1. Effect on broiler performance and efficiency of nitrogen retention. Poult. Sci., 75: 589-594. 
Deaton, J.W. (1995): The effect of early feed restriction of broilers on broiler performance. Poult. Sci., 74: 1280-1286.

Doyle, F. and Lesson, S. (1996): Compensatory growth in farm animals. Review presented to Department of Animal and Poultry Science, University of Guelph. Guelph, Ontario, Canada NIG 2WI.

Fisher, C. (1984): Fat deposition in borilers. In Fats in Animal Nutrition (Ed.Wiseman, J.), Proceedings of $37^{\text {th }}$ Easter School in Agricultural Science, University of Nottingham, Butterworths, London, pp. 437-470.

Fontana, E.A.; Weaver, W.D.; Jr; Denbow, D.M. and Watkins, B.A. (1993): Early feed restriction of broilers: Effects on abdominal fat pad, liver, and gizzard weights, fat deposition, and carcass composition. Poult. Sci., 72: 243-250.

Gous, R.M. (1977): Uptake of amino acids invitro in chickens previously subjected to three methods of dietary restriction. Br. Poult. Sci., 18: 511.

Holsheimer, J.P. and Veer Kamp, C.H. (1992): Effect of dietary energy, protein and lysine content on performance and yields of two strains of male broiler chicks. Poult. Sci., 71: 872-879.

Jones, G.P.D. and Farrel, D.J. (1992): Early-life food restriction of chicken II. Effect of food restriction on the development of Fat tissue. Br. Poult. Sci., 33:589 -601.

Jones, R.L. and Wiseman (1985): Effect of nutrition on broiler carcass composition: influence of dietary energy content in the starter and finisher phases. Br. Poult. Sci., 26: 381-388.

Kuhn, E.R.; Darras, V.M.; Gysemans, C.; Decuypere, E.; Berghman, L.R. and Buyse, J. (1996): The use of intermittent lighting in broiler raising 2 Effects on the somatotrophic and thyroid axes and on plasma testosterone levels. Poult. Sci., 75: 595-600.

Lawrence, T.L.J. and Fowler, V.R. (1997): Growth of farm animals. $\mathrm{CAB}$ International. All rights reserved. CAB International, $1^{\text {st }}$ ed. Library of Congress Cataloging. London, UK. Pp217-230.

Leeson, S.; Summers, J.D. and Caston, L.J. (1991): Diet dilution and compensatory growth in broilers. Poult. Sci., 70: 867-873.

Leeson, S. and Zubair, A.K. (1997): Nutrition of the broiler chicken around the period of compensatory growth Poult. Sci.., 76: 992-999. 
Lippens, M.; Huyghebaert, G. and De Groote, G. (2002): The fficiency of nitrogen retention during compensatory growth of foodrestricted broilers. Br. Poult. Sci., 43: 669-676.

Lippens, M.; Room, G.; De Groote, G. and Decuypere, E. (2000): Early and temporary quantitative food restriction of broiler chickens. 1-Effects on performance characteristics, mortality and meat quality. Br. Poult. Sci., 41: 343-354.

Moran, E.T.; J.R.; Bushong, R.O. and Bilgili, S.F. (1992): Reduced dietary crude protein for broiler while satisfying amino acid requirements by least cost formulation live performance, litter composition and yield of fast-food carcass cuts at six weeks. Poult. Sci., 71: 1687-1694.

N.R.C. (1994): Nutrient requirements of poultry. $9^{\text {th }}$ ed National Academy press, Washington, D.C., USA.

Palo, P.E.; Sell, J.L.; Piquer, F.J.; Soto-Salanova, M.F. and Vilaseca, L. (1995): Effect of early nutrient restriction on broiler chickens.1.Performance and development of the gastrointestinal tract. Poult. Sci., 74 (1): 88-101.

Plavnik, I. and Hurwitz, S. (1985): The performance of broiler chicks during and following a severe feed restriction at an early age. Poult. Sci., 64: 348-355.

Plavnik, I. and Hurwitz, S. (1988): Early feed restriction in chicks. Effect of age, duration and sex. Poult. Sci, 67: 384-390.

Plavnik, I. and Hurwitz, S. (1990): Performance of broiler chickens and turkey poults subjected to feed restriction or feeding of lowprotein or low-sodium diets at an early age. Poult. Sci., 69:945952.

Plavnik, I. and Hurwitz, S. (1991): Response of broiler chickens and turkey poults to food restriction of varied severity during early life. Br. Poult. Sci, 32:343-352.

Saleh, K.; Attia, Y.A. and Younish, H. (1996): Effect of feed restriction and breed on compensatory growth, abdominal fat and some production traits of broiler chicks. Archiv. Für Geflügelkunde, 60(4): 153-159.

Santoso, U.; Tanaka, K. and Ohtani, S. (1995): Early skip-a-day feeding of female broiler chicks fed high-protein realimentation diets: performance and body composition. Poult.Sci. 74:494-501.

SAS/STAT (1990): User's Guide. Version 6, $4^{\text {th }}$ Ed. Vol. 1. SAS institute, Cary, NC. 
Urdaneta-Rincon, M. and Leeson, S. (2002): Quantitative and qualitative feed restriction on growth characteristics of male broiler chickens. Poult. Sci., 81: 679-688.

Walaa Abdel-Razik, (1995): Effect of reduced dietary crude protein on broiler performance while satisfying essential amino acid requirements. Alex. J. Vet. Sci., 11 (4): 421-428.

Yu, M.E.; Robinson, F.E.; Cpandinin, M.T. and Bodnar, L. (1990): Growth and body composition of broiler chickens in response to different regimens of feed restriction. Poult. Sci., 69: 20742081.

Zubair, A.K. and Leeson, S. (1994): Effect of varying periods of nutrient restriction on growth performance and carcass characteristics of broiler chickens. Poult. Sci., 73: 129-136

Zubair, A.K. and Leeson, S. (1996): Compensatory growth in the broiler chicken. (Review), World's Poultry Science Journal, 52; July, 189-201. 